\title{
PENGARUH MODAL KERJA TERHADAP PROFITABILITAS PADA PERUSAHAAN KOSMETIK YANG TERDAFTAR DI BURSA EFEK INDONESIA
}

\author{
Yosi Andra Yani ${ }^{1}$, Lidya Martha ${ }^{2}$ \\ ${ }^{1,2)}$ Sekolah Tinggi Ilmu Ekonomi KBP \\ Email: Yosiandrayani05@gmail.com \\ Email Pembimbing: lidyam83@gmail.com
}

\begin{abstract}
This research aims to know whether there is the influence of working capital against profitability. Objects chosen by researchers are companies cosmetics listed in indonesia stock exchange. Research is done for observation in 2006-2015.The kind of data is taken from secondary data. The data collected from the official site of the indonesia stock exchange in the form of financial reports. While the sample was calculated by method purposive sampling, to achieve three of cosmetics company listed on the indonesian stock. Analysis techniques the data used was simple regression, the $T$, and the $R^{2}$ using eviews program. Based on test $T$ be seen that working capital influential positive and significantly to profitability, shown with probabilities < it 0.05 namely 0.0001. Based on the $R^{2}$ known that the value of $0.436227 R^{2}$, this shows that profitability cosmetics company listed on the indonesian stock of 43,62\% can be explained by variable independent. While the rest determined by variables outside this research
\end{abstract}

\section{Keywords: Working Capital and Profitability}

\section{PENDAHULUAN}

Latar Belakang

Pada dasarnya setiap perusahaan, didalam menjalankan usahanya, baik yangbergerak dalam bidang perdagangan, perindustrian, maupun jasa, pasti mempunyai tujuan tertentu yaitu mendapatkan laba sebesar-besarnya dengan menggunakan sumber daya yang dimiliki seefisien mungkin. Untuk itu perusahaan harus mempersiapkan strategi untuk meningkatkan hasil produksinya yang dalam hal ini dana yang dipergunakan untuk melangsungkan kegiatan operasi sehari-hari disebut modal kerja.

Alasan utama mengapa modal kerja penting dibahas dalam usaha meningkatkan profitabilitas perusahaan yaitu pertama, modal kerja merupakan bagian dari pembelanjaan jangka pendek perusahaan yang sejalan dengan tujuan jangka pendek perusahaan adalah meningkatkan profitabilitas. Kedua,berdasarkan fungsi kerja, modal kerja bersifat fleksibel, relative bervariasi, dan berputar cepat (Syamsuddin, 2007).Bersifat fleksibel karena modal kerja mudah untuk ditambahkan atau dikurangkan jumlahnya. Bersifat variatif karena modal kerja berasal dari sumber yang beragam. Bersifat berputar cepat karena perputaran modal kerja umumnya kurang dari satu tahun. Ketiga, modal kerja merupakan bidang aktivitas yang berkesinambungan sekaligus menjadi pendukung utama operasional perusahaan. 
Laba bersih mengindikasikan profitabilitas perusahaan. Laba bersih mencerminkan pengendalian kepada pemegang ekuitas untuk periode bersangkutan. Semakin besar rasio profitabilitas maka semakin besar pulakemampuan perusahaan itu menghasilkan laba bagi pemilik modal sendirinya. Modal kerja tinggi maka profitabilitas juga tinggi, sesuai dengan teori Martono dan Agus Harjitto dalam Mutiya Hatta (2011) dan Ryan Azhari (2009).

Modal kerja tidak boleh terlalu besar atau terlalu kecil dan juga harus dijaga agar tidak menimbulkan masalah. Dalam pencapaian modal kerja yang tinggi, perusahaan harus menjalankan aktivitasnya dengan efisien dan efektif. Modal kerja yang cukup memungkinkan perusahaan untuk beroperasi dalam rangkapencapaian laba yang ditargetkan.

\section{Tujuan Penelitian}

Tujuan peneliti ini adalah meneliti tentang bagaimana pengaruh modal kerja dalam meningkatkan profitabilitas pada perusahaan kosmetik yang terdaftar di Bursa Efek Indonesia.

\section{Pengertian Profitabilitas}

Pada dasarnya tujuan suatu perusahaan adalah memperoleh laba atau keuntungan yang maksimal. Dengan memperoleh laba yang maksimal perusahaan dapat berbuat banyak bagi kesejahteraan pemilik, karyawan dan investor serta meningkatkan mutu produk dan melakukan investasi baru. Untuk itu perlu digunakan rasio profitabilitas guna menghitung keuntungan perusahaan. $\begin{array}{lll}\text { Tingkat } & \text { profitabilitas } & \text { yang } \\ \text { tinggi pada } & \text { perusahaan } & \text { akan } \\ \text { meningkatkan } & \text { daya saing } & \text { antar } \\ \text { perusahaan. } & \text { Perusahaan } & \text { yang }\end{array}$ memperoleh tingkat keuntungan yang tinggi akan membuka lini atau cabang yang baru serta memperbesar investasi atau membuka investasi baru terkait dengan perusahaan induknya. Tingkat keuntungan yang tinggi menandakan pertumbuhan perusahaan pada masa mendatang. Profitabilitas dinilai sangat penting, karena untuk melangsungkan hidupnya suatu perusahaan haruslah berada dalam keadaan yang menguntungkan atau profitable. Tanpa keuntungan akan sulit bagi perusahaan untuk menarik modal dari luar. Beberapa pengertian tentang profitabilitas yakni:

Menurut Riyanto (2011) profitabilitas adalah menggambarkan kemampuan perusahaan mendapatkan laba melalui semua kemampuan dan sumber yang ada seperti penjualan, kas, modal, jumlah karyawan, jumlah cabang dan sebagainya, Sedangkan Brigham dan Daves (2010) menyatakan bahwa profitabilitas adalah hasil akhir dari sejumlah kebijakan dan keputusan yang dilakukan oleh perusahaan, Menurut Sawir (2005) rasio profitabilitas merupakan hasil akhir bersih dari berbagai kebijakan dan keputusan manajemen. Rasio profitabilitas akan memberikan jawaban akhir tentang efektivitas manajemen perusahaan, rasio ini memberi gambaran tentang tingkat efektivitas pengelolaan perusahaan, Pendapat lain yang kemukakan Putra (2009) mengatakan bahwa rasio profitabilitas merupakan kemampuan perusahaan dalam menciptakan tingkat keuntungan baik dalam 
bentuk laba perusahaan maupun ekonomis penjualan, aset bersih perusahaan maupun modal sendiri (stakeholders equity), Menurut Kasmir (2008) "rasio profitabilitas merupakan rasio yang digunakan untuk menilai kemampuan perusahaan dalam mencari keuntungan", Sedangkan menurut Sartono (2001) rasio profitabilitas adalah kemampuan perusahaan memperoleh laba dalam hubungannya dengan penjualan, total aktiva, maupun modal sendiri.

Berdasarkan pendapat diatas
dapat disimpulkan bahwa
profitabilitas adalah ukuran efektifitas
manajemen berdasarkan hasil
pengembalian yang dihasilkan dari
volume penjualan, total aktiva dan
modal sendiri.

\section{Pengertian Modal Kerja}

Untuk mengetahui keberhasilan suatu perusahaan dalam memperoleh laba dapat dilihat dari kemampuan perusahaan menggunakan modal kerja secara produktif. Adanya modal kerja yang cukup sangat penting bagi kelangsungan usaha perusahaan karena memungkinkan bagi perusahaan untuk beroperasi dengan seekonomis dan seefisien mungkin dan perusahaan tidak mengalami kesulitan dalam memgembangkan produknya.

Modal kerja (working capital) didefinisikan sebagai modal yang digunakan untuk membiayai operasional perusahaan sehari-hari, terutama yang memiliki jangka waktu pendek. Pengertian Modal kerja adalah investasi total perusahaan pada aktiva lancar atau aktiva yang diharapkan dapat dikonversi menjadi kas dalam waktu satu tahun atau kurang dari satu tahun (keown et al, 2010). Modal kerja menurut Kasmir (2011) "Modal yang digunakan untuk kegiatan operasi perusahaan. Modal kerja diartikan sebagai investasi jangka pendek yang ditanamkan dalam aktiva lancar atau aktiva jangka pendek, seperti kas, bank, surat-surat berharga, piutang, persediaan dan aktiva lancar lainnya". S. Mansyur (2004), menyebutkan " Modal kerja berarti net working capital atau kelebihan aktifa lancar terhadap hutang lancar, sedang untuk modal kerja sebagai aktiva lancar digunakan istilah modal kerja bruto (gross working capital)".

Modal kerja menurut Brigham dan Houston (2006) yaitu "Modal kerja yang diartikan seluruh aktiva lancar dikurangi dengan utang lancar, yang dinamakan modal kerja bersih". Sedangkan menurut Djarwanto (2004) "Modal kerja dapat didefinisikan dalam beberapa fungsi. Salah satunya fungsi daripada dana dalam menghasilkan pendapatan, dimana hanya jumlah dana yang digunakan selama periode akuntansi yang dimaksudkan untuk menghasilkan pendapatan jangka pendek saja, yaitu berupa kas, persediaan barang, piutang (setelah dikurangi profit margin), dan penyusutan aktiva tetap". Kemudian berbeda halnya dengan yang dikemukakan oleh Kasmir (2008) yaitu "Modal kerja merupakan modal yang digunakan untuk pembiayaan jangka pendek, seperti pembelian bahan baku, pembayaran gaji dan upah, serta biaya-biaya operasional lainnya".

Berdasarkan uraian beberapa definisi diatas, dapat disimpulkan bahwa modal kerja merupakan 
keseluruhan dari aktiva lancar yang digunakan untuk pembiayaan jangka pendek atau biaya operasional perusahaan selama priode akuntansi untuk menghasilkan pendapatan yang utama sesuai dengan tujuan utama didirikannya perusahaan.

Mengenai pengertian modal kerja kemudian Bambang Riyanto (2001) mengemukakan adanya beberapa konsep yaitu: Pertama, Konsep Kuantitatif yang mendasarkan pada kuantitas dari dana yang tertanam dalam unsur-unsur aktiva lancar di mana aktiva ini merupakan aktiva yang sekali berputar kembali dalam bentuk semula atau aktiva di mana dana yang tertanam didalamnya akan bebas lagi dalam waktu yang pendek. Dengan demikian modal kerja menurut konsep ini adalah keseluruhan dari jumlah aktiva lancar. Modal kerja dalam pengertian ini sering disebut modal kerja bruto ( gross working capital). Kedua, Konsep Kualitatif , apabila konsep pada kuantitatif modal kerja itu hanya dikaitkan dengan besarnya jumlah aktiva lancar saja, maka pada konsep kualitatif ini pengertian modal kerja juga dikaitkan dengan besarnya jumlah utang lancar atau utang yang segera harus dibayar. Dengan demikian maka sebagian dari aktiva lancar ini harus disediakan untuk memenuhi kewajiban financial yang segera harus dilakukan, dimana bagian aktiva lancar ini tidak boleh digunakan untuk membiayai operasinya dalam lancar di atas utang lancarnya. Modal kerja dalam pengertian ini sering disebut modal kerja neto (net working capital). Ketiga Konsep Fungsional, Konsep ini mendasarkan pada fungsi dari dana dalam menghasilkan pendapatan (income). Setiap dana yang dikerjakan atau digunakan dalam perusahaan adalah dimaksudkan untuk menghasilkan pendapatan. Ada sebagian dana yang digunakan dalam suatu periode akuntansi tertentu yang seluruhnya langsung menghasilkan pendapatan bagi periode tersebut (current income) dan ada sebagian dana lain yang juga digunakan untuk menghasilkan carrent income. Bambang Riyanto (2001).

\section{Hubungan Modal Kerja Dengan Profitabilitas}

Modal kerja merupakan
bagian dari aspek likuiditas,
sedangkan Earning Per Share
merupakan salah satu rasio yang
digunakan untuk mengukur efisien
penggunaan modal dalam suatu
perusahaan. Pada kenyataannya
setiap perusahaan selalu
memperhatikan profitabilitasnya, dimana setiap perusahaan ingin mendapatkan laba yang sebanyakbanyaknya tanpa harus memperhatikan resiko yang terjadi. Oleh karena itu setiap perusahaan harus memperhatikan benar-benar dalam mengelola atau mengatur modal kerja yang ada dengan seefisien mungkin.

Modal kerja merupakan unsur yang berperan dalam menghasilkan pendapatan. Ketidaktepatan jumlah modal kerja yang dibutuhkan akan mengakibatkan kegiatan perusahaan terganggu, dan jika hal ini terus menerus berlangsung, maka akan mempengaruhi kelangsungan kegiatan perusahaan. Penerapan modal yang tepat akan lebih mendorong pencapaian pertumbuhan dan perluasan kegiatan perusahaan. 
Yang mendasari manajemen modal kerja yang sehat adalah dua keputusan yang menyangkut persoalan dasar perusahaan Subardi (2010), yaitu: (a) Tingkat investasi optimal dalam aktiva lancar. (b) Campuran pembelanjaan jangka pendek dan pembelanjaan jangka panjang yang digunakan untuk mendukung investasi dalam aktiva lancar

\section{Keputusan-keputusan}

tersebut dipengaruhi oleh hasil yang diharapkan dari profitabilitas. Mengurangi tingkat investasi aktiva lancar, asalkan masih mampu memenuhi penjualan, akan mengarah pada peningkatan "Earning Per Share" perusahaan. Untuk investasi dimana biaya eksplisit pembelanjaan jangka pendek lebih kecil dari pada harga pembelanjaan jangka panjang, semakin besar porsi utang lancar maka semakin besar profitabilitas perusahaan Subardi (2010). Dari keterangan di atas dapat disimpulkan bahwa hubungan antara modal kerja dan profitabilitas adalah komposisi modal kerja yang tepat akan pengaruh kepada tingkat profitabilitas.

\section{METODE PENELITIAN}

Jenis penelitian yang ada dalam penelitian ini adalah penelitian kuantitatif, yaitu data penelitian yang berbentuk angka atau data kualitatif yang diangkakan atau scoring dikemukakan oleh Sugiyono (2008). Penelitian kuantitatif adalah pendekatan ilmiah terhadap pengambilan keputusan manajerial dan ekonomi, Kuncoro (2011). Penelitian ini dilakukan dengan menggunakan penelitian kuantitatif karena penelitian ini bersifat menganalisa laporan Keuangan Perusahaan Sektor Kosmetik dan
Keperluan Rumah Tangga yang Terdaftar di Bursa Efek Indonesia (BEI) dan menafsirkan hasilnya dalam bentuk angka-angka.

Populasi adalah seluruh unit analisis yang diteliti dalam penelitian, baik lembaga atau instansi maupun dalam wujud manusia. Sugiyono (2008) menyatakan bahwa populasi adalah wilayah generalisasi yang terdiri atas objek/subjek yang mempunyai kuanlitas dan karakteristik tertentu. ditetapkan oleh peneliti untuk dipelajari dan kemudian ditarik kesimpulan. Populasi yang digunakan dalam penelitian ini adalah perusahaan manufaktur yang bergerak dalam bidang Komestik dan Keperluan Rumah Tangga yang terdaftar di Bursa Efek Indonesia (BEI).

Sampel pada penelitian ini dipilih berdasarkan teknik pengumpulan sampel purposive sampling dimana penelitian ini tidak dilakukan pada seluruh populasi, tapi terfokus pada target dengan mempertimbangkan kriteria-kriteria tertentu yang telah dibuat terhadap objek yang sesuai dengan tujuan penelitian, dalam hal ini penelitian dilakukan pada perusahaan-perusahaan yang terdaftar di Bursa efek Indonesia.

Adapun kriteria pemilihan sampel adalah sebagai berikut: (a)Perusahaan-perusahaan yang terdaftar di BEI tahun 2011 atau sebelumnya. (b) Perusahaanperusahaan yang dimaksud adalah perusahaan yang bergerak dalam bidang kosmetik. (c) Perusahaanperusahaan yang menerbitkan laporan keuangan secara periodik 2011-2015 yang tersedia di BEI. (d) Data perusahaan yang tersedia untuk dianalisis. Berdasarkan Kriteria di 
atas sehingga terdapat 3 perusahaan kosmetik yang menjadi sampel penelitian yaitu :

1. PT. Mustika Ratu Tbk

2. PT. Martina Berto Tbk

3. PT. Mandom Indonesia Tbk

Definisi operasional variable yang digunakan terdiri dari variable independen dan variable dependen, dimana variabel dependenya adalah Profitabilitas sedangkan variable independennya adalah Modal Kerja.

\section{Definisi Operasional Penelitian}

\begin{tabular}{|c|c|c|c|c|}
\hline No & Variabel & Definisi & Pengukuran & Sumber \\
\hline 1 & $\begin{array}{l}\text { Modal } \\
\text { Kerja }\end{array}$ & $\begin{array}{l}\text { Merupakan modal } \\
\text { yang digunakan } \\
\text { untuk membiayai } \\
\text { operasional } \\
\text { perusahaan sehari- } \\
\text { hari, terutama yang } \\
\text { memiliki waktu } \\
\text { jangka pendek. }\end{array}$ & $\begin{array}{l}\text { Modal Kerja = Aktiva } \\
\text { lancar }- \text { Utang lancar }\end{array}$ & $\begin{array}{l}\text { Brigham dan } \\
\text { Houston } \\
(2006)\end{array}$ \\
\hline 2 & $\begin{array}{l}\text { Profitabilit } \\
\text { as }\end{array}$ & $\begin{array}{l}\text { Merupakan rasio } \\
\text { yang digunakan } \\
\text { untuk } \\
\text { membandingkan } \\
\text { antara jumlah laba } \\
\text { bersih dan dibagi } \\
\text { dengan total aktiva. }\end{array}$ & $\begin{array}{l}\text { Return on Asset=Net } \\
\text { Income/ Total } \\
\text { Assetx } 100 \%\end{array}$ & $\begin{array}{l}\text { Syafitri, } \\
\text { Sulaksono, } \\
\text { Wibowo } \\
(2016)\end{array}$ \\
\hline
\end{tabular}

Teknik analasis data pada penelitian ini adalah menggunakan uji teknik analisis deksriptif dimana melihat seberapa erat hubungan antara variable $\mathrm{x}$ dan $\mathrm{y}$. kemudian menggunakan ujinormalitas dan uji stasioneritas. Selanjutnya analisis regresi sederhana, uji kelayakan model dengan menguji uji t, dan uji $R^{2}$.Rumus persamaan uji regresi sederhana adalah sebagai berikut:

$$
\mathrm{Y}=a+\beta 1 \mathrm{x}+\mathrm{e}
$$

\section{Dimana :}

$$
\begin{array}{ll}
\mathrm{Y} & =\text { Profitabilitas } \\
a & =\text { Konstanta } \\
\beta & =\text { Koefisien regresi } \\
\mathrm{X} & =\text { Modal Kerja } \\
\varepsilon & =\text { error }
\end{array}
$$


HASIL DAN PEMBAHASAN

Uji Deskriptif Statistik Variabel Penelitian

Variabel yang diukur dalam penelitian ini yaitu Modal Kerja Bersih dan Retrun On Asset. Berikut penjelasan kondisi variabel Modal
Kerja dan profitabilitas pada perusahaan kosmetik yang terdaftar di Bursa Efek Indonesia. Hasil pengujian statistik deskriptif pada penelitian ini di sajikan pada tabel 1 berikut :

Table 1

Hasil Uji Deskriptif Statistik Variabel Penelitian

\begin{tabular}{lccccc}
\hline \hline Variable & $\mathbf{N}$ & Minimum & Maksimum & Mean & StandarDeviasi \\
\hline $\mathrm{X}$ & 30 & 91636.00 & 889742.0 & 332011.3 & 183489.4 \\
$\mathrm{Y}$ & 30 & -7.060000 & 26.20000 & 6.917000 & 6.647654 \\
\hline \hline
\end{tabular}

Sumber : Data Diolah

Pada tabel 1 diatas menunjukkan bahwa jumlah data yang digunakan dalam penelitian ini adalah sebanyak 30 data sampel Modal Kerja (Net Working Capital) dan Profitabilitas (ROA) diperoleh dari Bursa Efek Indonesia (BEI) periode tahun 2006-2015.

Data Modal Kerja (Net Working Capital) memiliki nilai terendah (minimum) sebesar 91636.00 dan nilai tertinggi (maksimum) sebesar 889742.0. Adapun nilai terendah tersebut terdapat pada perusahaan MBTO (Martina Berto) pada tahun 2009. Sedangkan nilai tertinggi terdapat pada perusahaan TCID (Mandom Indonesia) pada tahun 2015. Nilainilai tersebut menunjukkan bahwa respon terhadap Modal Kerja (Net Working Capital) adalah antara Rp
91.636.000 sampai dengan $\mathrm{Rp}$ 889.742.000. Sementara standar devesiasi sebesar Rp 183.489.400 menunjukan simpangan data yang relative kecil, karena nilainya yang lebih kecil dari pada nilai mean-nya yaitu sebesar Rp 332.011.300.

Data Profitabilitas (ROA) mempunyai tingkat terendah (minimum) adalah $-7.06 \%$ dan paling tinggi ( maksimum) sebanyak $26.20 \%$ - Adapun data terendah tersebut terdapat pada perusahaan MBTO (Martina Berto) tahun 2006. Sedangkan data tertinggi tersebut terdapat pada perusahaan TCID (Mandom Indonesia) tahun 2015. kemudian rata-rata sebesar $6.92 \%$ dengan nilai standar deviasi sebesar $6.65 \%$ menunjukkan simpangan data relative besar, karena nilainya yang lebih besar daripada nilai mean-nya. 


\section{Uji Stasioneritas}

Table 2

Uji Stasioneritas variabel penelitian

\begin{tabular}{lccc}
\hline \hline Variabel & \multicolumn{3}{c}{ Tingkat Stasioneritas } \\
\cline { 2 - 4 } & \multicolumn{3}{c}{ Level } \\
\cline { 2 - 4 } & t-statistic & Probability & Keterangan \\
\hline X & -0.466269 & 0.8841 & TidakStasioner \\
Y & -1.545131 & 0.4970 & TidakStasioner \\
\hline
\end{tabular}

Sumber: Data diolah

Dilihat dari tabel 2 di atasperilaku data dari masing-masing variabel. berdasarkan hasil pengujian Augmented Dickey-Fuller (ADF) pada tingkat level yang mencangkup intercept, dapat dilihat bahwa tidak ada variabel pada tingkat ini nilai absolut ADF nya lebih kecil dari nilai kritis dengan derajat keyakinan 0.05 . Sehingga, perlu dilakukan uji derajat integrasi atau uji stasioneritas pada derajat difference sampai semua variabel yang diamati stasioner pada derajat yang sama.

Tabel 3

Hasil Uji Derajat Integrasi (First Difference)

\begin{tabular}{lccl}
\hline \hline Variabel & \multicolumn{3}{c}{ Tingkat Stasioneritas } \\
\cline { 2 - 4 } & \multicolumn{3}{c}{ Level } \\
\cline { 2 - 4 } & t-statistic & Probability & Keterangan \\
\hline $\mathrm{X}$ & -4.531595 & 0.0013 & Stasioner \\
$\mathrm{Y}$ & -5.143764 & 0.0003 & Stasioner \\
\hline \hline
\end{tabular}

Sumber: Data diolah

Pada tabel 3 diatas menunjukkan hasil uji statistik ADF pada First Difference yang menunjukkan bahwa hipotesis nol ditolak, dengan kata lain data pada variabel Modal Kerja dan Profitabilitas setelah diturunkan satu kali data menjadi stasioner. Dengan ini Absolut ADF lebih kecil dari nilai kritis pada tingkat keyakinan 0,05. Artinya semua variabel tersebut sudah tidak mengandung masalah akar unit dan mempunyai kondisi data stasioner pada tingkat atau derajat integrasi satu. 


\section{Uji Normalitas}

Tabel 4

Hasil Uji Normalitas Data

\begin{tabular}{lcccc}
\hline \hline Variabel & $\mathbf{N}$ & Jarque-Bera & Probability & Keterangan \\
\hline $\mathrm{X}$ & 29 & 6.671533 & 0.035587 & Tidak Normal \\
$\mathrm{Y}$ & 29 & 1.504181 & 0.471380 & Normal \\
\hline
\end{tabular}

Sumber : Data Diolah

Dilihat dari table 4 di atas Probability untuk Modal Kerja (Net Working Capital) bernilai nol, berarti data untuk variable tersebut tidak normal karena syarat untuk normal adalah probability jarque-bera > 0,05 . Untuk menormalkan data Modal Kerja (Net Working Capita) maka data asli ditransformasikan dengan menggunakan transformasi Square, transformasi Square dilakukan dengan membalik nilai asli, yaitu dengan rumus $=$ SQRT (Data asli) menggunakan rumus excel transformasi. Kemudian data dilakukan pengolahan kembali. Maka hasil dari pengolahan dilihat di bawah ini.

Tabel 5

Hasil Uji Normalitas Data Diolah Kembali

\begin{tabular}{lcccl}
\hline Variabel & $\mathbf{N}$ & Jarque-Bera & Probability & Keterangan \\
\hline $\mathrm{X}$ & 29 & 0.294650 & 0.863014 & Normal \\
$\mathrm{Y}$ & 29 & 1.504181 & 0.471380 & Normal \\
\hline \hline
\end{tabular}

Sumber : Data diolah

Dari Tabel 5 diatas terlihat pada data Probability untuk Net Working Capital bernilai $86,3 \%$, berarti data telah normal karena probability jarque-bera $>0,05$.

\section{Analisis Regresi Sederhana}

Pada penelitian ini, analisis data dilakukan dengan menggunakan teknik analisis regresi sederhana untuk mengolah dan membahas data yang telah diperoleh dan untuk menguji hipotesis yang diajukan. Variable C merupakan constant (konstan), Profitabilitas (ROA) merupakan Y, Modal Kerja (Net Working Capital) merupakan variable $\mathrm{X}$, coefficient (koefisien) merupakan parameter dari permasalahan, probability (probabilitas) adalah angka yang menunjukkan kemungkinan terjadi suatu kejadian 
Tabel 6

Hasil Uji Regresi Linier Sederhana

Dependent Variable: Y

Method: Least Squares

Date: 09/29/17 Time: 19:49

Sample (adjusted): 129

Included observations: 29 after adjustments

\begin{tabular}{lrlll}
\hline \multicolumn{1}{c}{ Variable } & Coefficient & Std. Error & t-Statistic & Prob. \\
\hline \hline \multicolumn{1}{c}{ C } & -8.772236 & 3.590648 & -2.443079 & 0.0214 \\
\multicolumn{1}{c}{0.028277} & 0.006187 & 4.570733 & 0.0001 \\
\hline \hline R-squared & 0.436227 & Mean dependent var & 7.048621 \\
Adjusted R-squared & 0.415346 & S.D. dependent var & 6.725420 \\
S.E. of regression & 5.142435 & Akaike info criterion & 6.179402 \\
Sum squared resid & 714.0051 & Schwarz criterion & 6.273699 \\
Log likelihood & -87.60133 & Hannan-Quinn criter. & 6.208935 \\
F-statistic & 20.89160 & Durbin-Watson stat & 1.022300 \\
Prob(F-statistic) & 0.000097 & & \\
\hline
\end{tabular}

Sumber: Data Eviews

Dari table 6 diatas, dapat dituliskan persamaan sebagai berikut:

Profitabilitas $=-8.772236+0.028277$ Modal kerja

Keterangan: (a). Nilai konstanta sebesar -8.772236 memiliki arti bahwa bila modal kerja diasumsikan nol, maka Profitabilitas (ROA) mengalami penurunan sebesar 8.772236. (b). Nilai $X=0.028277$ dengan hubungan positif menunjukkan bahwa apabila Modal Kerja (Net Working Capital) mengalami peningkatan sebesar satu satuan, maka Profitabilitas (ROA) perusahaan kosmetik akan mengalami peningkatan sebesar 0.028277 satuan atau $2.83 \%$

\section{Uji Hipotesis}

Uji T

Uji t digunakan untuk melihat besarnya berpengaruh dari variable bebas secara parsial terhadap variable terikatnya. Untuk mengetahui pengaruh variable bebas secara parsial terhadap variable terikatnya maka hasil thitung dibandingkan dengan tingkat $\alpha=0,05$. Jika thitung $<$ 0,05 maka Ho ditolak artinya secara parsial variable bebas memiliki pengaruh yang signifikan terhadap variable terikat dan sebaliknya. Dimana variable independen atau variable bebasnya Modal Kerja (Net Working capital) sedangkan variable dependen atau variable terikatnya adalah Profitabilitas (ROA).

Dari hasil pengolahan data dihasilkan Modal Kerja menunjukkan $\mathrm{t}_{\text {hitung }} 4.570733$ dengan nilai signifikan 0.0001 kecil dari tingkat alpha 0,05 dan koefisien $\beta$ sebesar 
0.028277 menunjukkan nilai positif. $\mathrm{Hal}$ ini berarti bahwa $\mathrm{Ha}$ diterima, $\mathrm{H}_{\mathrm{o}}$ ditolak dimana Modal Kerja berpengaruh positif dan signifikan terhadap Profitabilitas.

\section{Koefisien Determinasi $\left(\mathbf{R}^{\mathbf{2}}\right)$}

Koefisien Determinasi $\left(\mathrm{R}^{2}\right)$ berfungsi untuk melihat sejauh mana variable bebas dapat menjelaskan variabel terikat secara persentase. Dari hasil pengolahan data ditemukan nilai $R$-Squared 0.436227 ini berarti variable bebas Modal kerja (Net Working Capital) mampu menjelaskan Profitabilitas (ROA) sebesar 43,62 \% sedangkan sisanya $56,38 \%$ dijelaskan oleh faktor lain yang tidak diteliti dalam penelitian ini. Misalnya, Perputaran Kas, Perputaran Persediaan dan Perputaran Piutang

\section{Pembahasan}

\section{Pengaruh Modal Kerja Terhadap Profitabilitas}

Dari tabel 6 dihasilkan nilai koefisien regresi untuk variable Modal Kerja yang diproxy oleh (Net Working Capital) sebesar Rp 0.028277 bertanda positif dengan nilai probabilitas $0.0001<0,05$ yang berarti bahwa Modal Kerja mempunyai pengaruh yang signifikan terhadap Profitabilitas yang diproxy oleh (Retrun On Asset). Dengan demikian dapat disimpulkan $\mathrm{H}_{\mathrm{a}}$ diterima.

Sejalan dengan penelitian Utami dan Dewi (2016) meneliti mengenai pengaruh manajemen modal kerja terhadap profitabilitas perusahaan manufaktur yang terdaftar di BEI. Hasil penelitiannya mengemukakan bahwa variabel perputaran kas, perputaran piutang dan perputaran persediaan memiliki pengaruh positif dan signifikan terhadap profitabilitas.
Sedangkan penelitian Satrya dan Lestari (2012) meneliti mengenai pengaruh perputaran modal kerja terhadap profitabilitas perusahaan. Hasil penelitiannya menunjukkan bahwa variabel perputaran modal kerja, perputaran kas dan perputaran persediaan memiliki pengaruh positif dan signifikan terhadap profitabilitas (ROI).

Sebaliknya dengan penelitian Veronica, dkk menyatakan perputaran Modal Bersih tidak berpengaruh secara signifikan terhadap laba bersih, perputaran persediaan tidak berpengaruh secara signifikan terhadap laba bersih, perputaran piutang tidak berpengaruh secara signifikan terhadap laba bersih, tetapi perputaran kas berpengaruh secara signifikan terhadap laba bersih.

Untuk hasil penelitian Nur Maslinda menyatakan bahwa Modal Kerja tidak berpengaruh signifikan terhadap Profitabilitas (ROA) dalam meningkatkan laba perusahaan. Hal ini disebabkan karena adanya penambahan kas dan setara kas akibat penekanan tingkat persediaan serta peningkatan piutang usaha sejalan dengan kenaikkan penjualan perusahaan.

\section{KESIMPULAN DAN SARAN Kesimpulan}

Berdasarkan hasil penelitian dan pembahasan yang telah disajikan pada bab-bab sebelumnya, maka dapat diambil kesimpulan bahwa:

Modal Kerja memiliki pengaruh positif dan signifikan terhadap Profitabilitas pada perusahaan kosmetik yang terdaftar di Bursa Efek Indonesia pada tahun 2006-2015 yang ditunjukkan dengan nilai Modal Kerja yang diproxy oleh (Net Working Capital) sebesar Rp 0.028277 dengan nilai probabilitas $0.0001<0,05$. 


\section{Saran Peneliti}

Bagi Manajemen, dari hasil pengujian yang telah dilakukan dapat diketahui bahwa Modal Kerja cendrung berpengaruh dalam meningkatkan Profitabilitas sehingga dengan demikian perlu diperhatikan oleh setiap perusahaan agar dapat berhati-hati dalam mengelola Modal Kerjadan agar dipergunakan seefektif dan seefisien mungkin untuk memperoleh keuntungan.

Selain dari Modal Kerja adapun faktor lain yang harus diperhatikan dalam meningkatkan Profitabilitas yaitu, pada bagian manajemen biaya produksi ataupun biaya operasi sehingga Profitabilitas

\section{DAFTAR PUSTAKA}

Angraini, I., \& Yusra, I. (2019). Pendekatan data panel terhadap return saham: studi empiris pada perusahaan LQ45. INARxiv.

Brigham, Eugene $F$ dan Houston, Joel F. 2006. Dasar-dasar Manajemen keuangan. Salemba Empat, Jakarta.

Elmawati Nte'esi, Dkk. 2015.

$\begin{array}{lr}\text { Analisis } & \text { Pengaruh } \\ \text { Perputaran } & \text { Modal } \\ \text { Kerja } & \text { Terhadap } \\ \text { Profitabilitas } & \\ \text { Perusahaan } & \text { Pada } \\ \text { PT.Indofood } & \text { Sukses } \\ \text { Makmur, } & \text { Tbk. } \\ \text { Universitas } & \text { Sam } \\ \text { Ratulangi Manado. }\end{array}$

Fadli, Achmad Agus Yasin. $2017 . \quad$ "Pengaruh Profitabilitas Terhadap Modal Kerja Pada dapat terus meningkat dan menarik minat calon investor karena kinerja perusahaan yang baik dalam mengelola keuangan.

Bagi peneliti selanjutnya, adapun keterbatasan pada penelitian ini yakni hanya mengunakan satu variable bebas yaitu modal kerja sehingga belum dapat menjelaskan secara mendalam mengenai faktorfaktor yang mempunyai keterkaitan dalam meningkatkan Profitabilitas. Maka dari itu, sebaiknya bagi peneliti selanjutnya perlu dilakukan penelitian selanjutnya terhadap faktor-faktor yang mempengaruhi dalam meningkatkan Profitabilitas selain Modal Kerja Bersih.

\section{Perusahaan Makanan \\ Dan Minuman Yang \\ Terdaftar Di Bursa Efek \\ Indonesia". Universitas \\ Pamulang.}

Frans Firnady. 2007. "Analisis Hubungan Modal Kerja Bersih Terhadap Profitabilitas pada PT. Pola Indah Gas Medan". Skripsi S-1. Fakultas Ekonomi Universitas Muhammadiyah Ponorogo.

Gusnita, E., \& Martha, L. (2019). Analisis Struktur Modal Dalam Memoderasi Pengaruh Kepemilikan Manajerial Dan Pertumbuhan Perusahaan Terhadap Nilai Perusahaan Di Indonesia. INA-Rxiv .

Hadya, R., Begawati, N., \& Yusra, I. (2017). Analisis Efektivitas Pengendalian Biaya, Perputaran Modal Kerja, dan Rentabilitas Ekonomi Menggunakan Regresi Data Panel. Jurnal Pundi, 01(03), 1-35. 
Hanafi, D., \& Yusra, I. (2019). Tangibility, liquidity, growth opportunity, dan leverage: studi pada perusahaan terdaftar di Bursa Efek Indonesia. INA-Rxiv, (2001).

Handayani, F., \& Martha, L. (2019). Hubungan Antara Profitabilitas Dengan Nilai Perusahaan Yang Dimoderasi Oleh Corporate Social Responsibility. INA-Rxiv.

Harmono. 2011. Manajeman Keuangan Berbasis Balanced Scorecard Pendekatan Teori, Kasus dan Riset Bisnis. Bumi Aksara, Jakarta.

Juliadi, Azuar dan Irfan. 2013. Metodologi Penelitian Kuantitatif untuk IlmuIlmu Bisnis. CitaPustaka Media Printis, Jakarta.

Juliati, Ni Wayan. 2013. Pengaruh Kebijakan Modal Kerja Terhadap Profitabilitas Pada Perusahaan Hotel dan Restoran di Bursa Efek Indonesia". Tesis S-2. Universitas Udayana Denpasar.

Julkarnain. 2011. "Pengaruh Modal Kerja, Perputaran Modal Kerja, Perputaran Kas, dan Perputaran Piutang Terhadap Profitabilitas Pada Perusahaan Industri Barang Konsumsi Yang Terdaftar Di Bursa Efek Indonesia Tahun 2008-2011". Skripsi S-1. Fakultas Ekonomi Universitas Maritim Ali Haji. Tanjuna Pinang.

Jumingan. 2006. Analisis
Laporan

Keuangan. PT

Bumi Aksara,

Jakarta.

Kasmir. 2008 .

Analisis

Laporan

Keuangan.

Rajawali

Persada,

Jakarta.

Kasmir. 2010.

Pengantar

Manajemen

Keuangan.

Kencana,

Jakarta.

Kurniawan, A., \& Yusra, I. (2019). Apakah profitabilitas dan nilai buku berdampak terhadap return saham?: studi empiris pada perusahaan LQ45. INA-Rxiv.

Martha, L., Sogiroh, N. U., Magdalena, M., \& Susanti, F. (2018). Profitabilitas dan Kebijakan Dividen terhadap Nilai Perusahaan. Jurnal Benefita, 3(2), 227-238.

Maslinda, Dahrani Nur. 2012. "Analisis Pengaruh Modal Kerja Dalam Meningkatkan

Profitabilitas Pada

Perusahaan Kosmetik Dan Keperluan Rumah Tangga Yang Terdaftar Di Bursa efek Indonesia" $\quad \mathrm{S}-1$. Universitas Muhammdadiyah Sumatra Utara.

Mulyana, Wilda. 2013. "Analisis Modal Kerja Dalam Meningkatkan 
Laba Bersih Pada

Perusahaan Nusantara

II (Persero) Tanjung

Morawa Medan". S-1.

Universitas

Muhammadiyah

Sumatra Utara

Nurhidayah, Ema. 2012

"Analisis Efeisiensi

Modal Kerja Untuk

Meningkatkan

Propitabilitas (Studi

Kasus Pada Distributor

Pupuk Sugih Waras di

Ponorogo"). Fakultas

Ekonomi Universitas

Muhammadiyah

Ponorogo.

Purnama, S., \& Mayliza, R. (2019).

Nilai Perusahaan Di Lihat Dari

Aspek Profitabilitas, Ukuran

Perusahaan Dengan Struktur

Modal Sebagai Variabel

Intervening. INA-Rxiv.

Puspitasari,

Desi.

2012. "Pengaruh

Perputaran

Modal

Kerja Terhadap

Profitabilitas

PT.Akashawira

Internasional, $\quad$ Tbk

STIE Widya Dharma

Pontianak.

Putra, A. D., \& Yusra, I. (2019). Peran profitabilitas dalam memoderasi pengaruh free cash flow terhadap kebijakan dividen di Indonesia. INA-Rxiv.

Qusibah, V. L., \& Yusra, I. (2019). Profitabilitas , dan Ukuran Perusahaan Sebagai Faktor Penentu Leverage Perusahaan Di Indonesia. Jurnal Pundi, 03(01), 13-26.

https://doi.org/10.31575/jp.v3i1.
125

Reimeinda, Veronica,dkk. 2016. Analisis Pengaruh Modal Kerja Terhadap Profitabilitas pada Industri Telekomunikasi di Indonesia. Universitas Sam Ratulangi Manado.

Sari, N. N., \& Yusra, I. (2018). Analisis Likuiditas, Leverage dan Kebijakan Dividen berdasarkan Siklus Hidup Perusahaan pada Saham LQ45. INA-Rxiv.

Satriya, I Made Dian dan Lestari Putu vivi. 2012. "Pengaruh Perputaran Modal Kerja Terhadap Profitabilitas

Perusahaan". Fakultas Ekonomi dan Bisnis Universitas Udayana (Unud), Bali, Indonesia.

Sawir,Agnes. 2005. Analisis Kinerja Keuangan dan Perencanaan Keuangan Perusahaan. cetakan ke5. Gramedia Pustaka Utama,Jakarta, 2005.

Smith, and Skousen. 2000. Akuntansi Intermediate. Volume Komprehensif. (Diterjemahkan oleh Tim Penerjemah). Jilid 1 (edisi IX). Erlangga, Jakarta.

$\begin{array}{lll}\text { Soemarso } & \text { S.R. } & 2009 .\end{array}$ Akuntansi Suatu Pengantar. (edisi IX). Salemba Empat, Jakarta.

Syafitri, Resky Amelia, dkk. $2016 . \quad$ "Pengaruh Komponen Modal Kerja 
Terhadap Profitabilitas

Perusahaan

Manufaktur Yang

Terdaftar Di BEI.

Politeknik Negeri

Batam.

Syafri Harahap, Sofyan. 2008. Analisa Kritis atas Laporan Keuangan. PT. Raja Grafindo Persada, Jakarta.

Utami, Made Sri dan Dewi S,

Made Rusmala. 2016.

"Pengaruh Manajemen

Modal Kerja Terhadap

Profitabilitas

Perusahaan

Manufaktur Yang

Terdaftar Di Bursa Efek

Indonesia”. Fakultas

Ekonomi dan Bisnis

Universitas Udayana

(Unud), Bali, Indonesia.

Wahyuni, I., \& Mayliza, R. (2019). Peran Kebijakan Deviden Dalam Memediasi Pengaruh

Profitabilitas Terhadap Nilai

Perusahaan. INA-Rxiv.
Yusra, I., Hadya, R., Begawati, N., \& Istiqomah, L. (2019). Panel data model estimation: the effect of managerial ownership, capital structure, and company size on corporate value Panel data model estimation: the effect of managerial ownership, capital structure, and company size on corporate value. Journal of Physics: Conference Series, 1175, 1-6. https://doi.org/10.1088/17426596/1175/1/012285

Yusra, I., Hadya, R., \& Fatmasari, R. (2019). The Effect of Retained Earnings on Dividend Policy from the Perspective of Life Cycle. Advances in Social Science, Education and Humanities Research, 203(Iclick 2018), 216-220.

Yusuf, D., \& Yusra, I. (2019). Faktorfaktor yang mempengaruhi struktur modal perusahaan. INARxiv. 